Hasan Hasan: Psikolinguistik: Urgensi dan Manfaatnya Pada Program Studi Pendidikan Bahasa Arab

\title{
PSIKOLINGUISTIK: URGENSI DAN MANFAATNYA PADA PROGRAM STUDI PENDIDIKAN BAHASA ARAB
}

\author{
Hasan* $^{*}$ \\ STIQ Amuntai, Kalimantan Selatan, Indonesia \\ Email: hasanbanjary@gmail.com
}

\begin{abstract}
Abstrak
Mata kuliah Psikolinguistik seharusnya mendapatkan perhatian yang lebih bagi prodi Pendidikan Bahasa Arab karena dengan psikolinguistik sebagai guru ataupun dosen bahasa Arab dapat memanfaatkan bagaimana mengajar bahasa Arab dengan baik dan melihat psikologi anak didik. Hasil penelitian pakar psikolinguistik dapat digunakan dalam memahami pemerolehan bahasa pertama maupun dalam pembelajaran bahasa kedua atau bahasa asing. Pasalnya, ruang lingkup kajian psikolinguistik sangat bermanfaat bagi pembelajaran bahasa. Di dalam kurikulum pendidikan bahasa Arab, mata kuliah psikolinguistik dimasukkan dalam kelompok mata kuliah proses belajar-mengajar, bukan pada kelompok mata kuliah linguistik/kebahasaan. Hal ini karena pokok bahasan dalam psikolinguistik sangat erat kaitannya dengan kegiatan proses belajar mengajar bahasa itu. ketika teori pemerolehan bahasa pertama dan kedua atau bahasa asing sudah diketahui untuk mengajarkan bahasa diharapkan tidak ada problem yang sulit ketika dalam proses mengajar. Makanya tidaklah berlebihan jika mengatakan psikolinguistik itu sangat berguna bagi mahasiswa PBA.
\end{abstract}

Kata kunci: Psikolinguistik, bahasa pertama, bahasa kedua

\section{PENDAHULUAN}

Salah satu bahasa yang sangat diminati dan sering dipelajari (baik di pendidikan formal maupun nonformal) terlebih lagi di Indonesia adalah bahasa Arab. Walaupun banyak dipelajari namun masih ada juga saja yang menganggap bahasa Arab itu sulit baik itu dari segi kalimat (kata dalam bahasa Indonesia) maupun dari segi yang lainnya. Stigma negatif tentang sulitnya belajar bahasa Arab sebenarnya merupakan propaganda Barat/kolonialis agar umat Islam sedikit demi sedikit menjauhi agamanya, karena bahasa Arab adalah bahasa Al Quran sehingga bila umat Islam jauh dengan Al Quran maka akan jauh pula dengan agamanya (Islam). ${ }^{1}$

\footnotetext{
${ }^{1}$ Hasan Hasan, "Keterampilan Mengajar Bahasa Arab Materi istima Menggunakan Media Lagu," Al Qalam: Jurnal Ilmiah Keagamaan dan Kemasyarakatan 10, no. 19 (2017): h. 128.
}

Jurnal Al Mi'yar Vol. 1, No. 2 Oktober 2018

Homepage https://jurnal.stiq-amuntai.ac.id/index.php/al-miyar 
Hasan Hasan: Psikolinguistik: Urgensi dan Manfaatnya Pada Program Studi Pendidikan Bahasa Arab

Dalam perkembangan pembelajaran bahasa Arab di Indonesia seringkali guru atau anak didik sebagai komponen utama dalam pembelajaran mengalami berbagai kesulitan dan permasalahan pembelajaran, baik persoalan yang bersumber dari anak didik maupun masalah-masalah yang ditemui oleh pengajar, sehingga dapat menghambat pada ketercapaian tujuan pembelajaran dengan baik. Hal ini dapat dimaklumi, mengingat banyaknya perbedaan-perbedaan sistem antara bahasa Arab sebagai bahasa kedua yang dipelajari dan sistem bahasa Indonesia yang sudah melekat erat pada diri anak didik di Indonesia. Perbedaan-perbedaan itu dapat dilihat misalnya pada aspek fonem, gramatikal atau kaedah bahasa, sistem kosa kata, dan gaya bahasa (uslub). Pengembangan pembelajaran bahasa memerlukan konsep yang valid dan tepat. Hal ini dapat dilakukan dengan meramu dan mengadopsi dari berbagai disiplin ilmu. Teori-teori yang diperoleh kemudian diolah menjadi teknik, metode dan pendekatan atau bahkan menjadi teori baru yang dapat dipergunakan dalam pembelajaran bahasa tersebut.

Di Indonesia, pembelajaran Bahasa Arab sebagai bahasa kedua (second language) sangat marak bahkan menjadi salah satu mata pelajaran wajib, mulai dari tingkat dasar sampai perguruan tinggi, khususnya pada sekolah atau lembaga pendidikan Islam yang berada dibawah naungan Kementrian Agama Republik Indonesia. Berbeda dengan bahasa Inggris, bahasa Arab sampai sekarang belum menjadi mata pelajaran yang diUNkan bagi sekolah/madrasah di bawah Kementrian Agama. Hal tersebut berimplikasi bahwa nilai bahasa Arab tidak menjadi syarat mutlak dalam kelulusan anak didik. Hal ini dapat menimbulkan kecemburuan bagi pemerhati bahasa Arab.

Materi bahasa merupakan objek kajian dari linguistik. ${ }^{2}$ Pembelajaran bahasa juga berkenaan dengan masalah kegiatan berbahasa. Sedangkan kegiatan berbahasa itu bukan hanya berlangsung secara mekanistik, tetapi juga berlangsung secara mentalistik, artinya sebagai proses yang berkenaan dengan mental (otak). Oleh karena itu dalam kaitannya dengan pembelajaran bahasa, termasuk juga dalam

Lihat juga Muhbib Abdul Wahab, Pemikiran Linguistik Tammam Hassan Dalam Pembelajaran Bahasa Arab (Jakarta: UIN Syarif Hidayatullah Jakarta, 2009), h. 2.

2 Menurut Leonard Bloomfield (1887-1949), bahasa baru dikaji secara ilmiah secara deskriptif dan komprehensif pada abad ke 19 lalu. Pencapaian ilmu bahasa (linguistik) dalam kajian ilmiahnya baru menjadi bagian dari proses pendidikan tradisional. Lihat Wahab, Pemikiran Linguistik Tammam Hassan Dalam Pembelajaran Bahasa Arab, 21. 
Hasan Hasan: Psikolinguistik: Urgensi dan Manfaatnya Pada Program Studi Pendidikan Bahasa Arab

pembelajaran bahasa Arab, maka studi kebahasaan (linguistik) perlu dilengkapi dengan studi antardisipliner, khususnya antara linguistik dan psikologi, yang lazim disebut psikolinguistik. Untuk mendapatkan kepahaman yang lebih mendalam mengenai psikolinguistik dan kontribusinya dalam rangka pembelajaran bahasa, maka dalam makalah ini penulis akan memfokuskan pembahasan pada pengertian Psikolinguistik, ruang lingkup Psikolinguistik dan kontribusi Psikolinguistik dalam pembelajaran bahasa Arab sebagai bahasa kedua (second language), yang diarahkan pada psikolinguistik sebagai media pengidentifikasi masalah dan langkah penyelesaian masalah.

Teori linguistik sebenarnya memberikan kepada kita bagaimana gambaran yang utuh tentang seluk-beluk bahasa33, bagaimana hakikat bahasa yang akan diajarkan dengan suatu metode. Pada awalnya ada dua aliran besar linguistik yang mengkonsentrasikan pemikirannya dalam analisis bahasa yaitu aliran struktualisme (al madrasah al binyawiyah) yang lebih menekankan kepada bentuk lahiriah bahasa dibandingkan dengan makna bathiniah dan yang kedua aliran generatif-transformatif (al madrasah al taulidiyah al tahwiliyyah) yang memberikan perhatian seimbang kepada bentuk lahiriah dan makna batiniah pada bahasa. ${ }^{4}$

\section{PEMBAHASAN}

\section{Peran Psikolinguistik dalam Pembelajaran Bahasa Arab}

\section{Pengertian Psikolinguistik}

Secara etimologi Psikolinguistik terbentuk dari dua kata psikologi dan linguistik, yakni dua bidang ilmu yang berbeda-beda dan masingmasing berdiri sendiri dengan metode dan prosedur yang berlainan. Secara harfiah psikologi berarti ilmu jiwa atau ilmu yang objek kajiannya adalah jiwa, sedangkan linguistik diartikan sebagai ilmu bahasa atau ilmu yang

3 Terdapat beberapa teori mengenai hubungan bahasa dan kebudayaan. Ada yang mengatakan bahasa itu merupakan bagian dari kebudayaan, tetapi ada pula yang mengatakan bahwa bahasa dan kebudayaan merupa-kan dua hal yang berbeda, namun mempunyai hubungan yang sangat erat, sehingga tidak dapat dipisahkan. Ada yang mengatakan bahwa bahasa sangat dipengaruhi kebudayaan, sehingga segala hal yang ada dalam kebudayaan akan tecermin di dalam bahasa. Sebaliknya, ada juga yang mengatakan bahwa bahasa sangat dipenga-ruhi kebudayaan dan cara berpikir manusia atau masyara-kat penuturnya. Ada yang beranggapan bahwa bahasa bagian dari kebudayaan atau dengan kata lain mempunyai hubungan subordinatif, dimana bahasa berada di bawah kebudayaan serta ada juga yang menganggap sebagai hubungan koordinatif, sama kedudukannya. Lihat Hasan Hasan, Penerjemahan Arab-Indonesia (Antara Bahasa dan Budaya) (Banjarbaru: Atap Buku, 2017), 1.

4 Aziz Fachrurrozi dan Erta Mahyudin, Pembelajaran Bahasa Asing (Jakarta: Bania Publishing, 2010), h.20. 
Hasan Hasan: Psikolinguistik: Urgensi dan Manfaatnya Pada Program Studi Pendidikan Bahasa Arab

mengambil bahasa sebagai objek kajiannya. Guna memperoleh pengertian yang jelas tentang psikolinguistik secara terminologi, maka akan lebih baik jika penulis mengupas terlebih dahulu sekilas tentang psikologi dan linguistik, yang notebenenya merupakan asal atau sumber dari munculnya psikolinguistik.

Psikologi berasal dari berasal dari bahasa Yunani Kuno, yaitu dari akar kata psyche yang berarti jiwa, ruh, sukma dan logos yang berarti ilmu. Jadi, secara harfiah psikologi berati "ilmu jiwa" atau ilmu yang objek kajiannya adalah jiwa. Psikologi yang diartikan sebagai ilmu jiwa berlaku ketika Psikologi berada atau menjadi bagian dari filsafat, bahkan pada tahunlima puluhan, dalam kepustakaan Indonesia ilmu jiwa lazim dipakai sebagai padanan Psikologi. Namun, kini istilah ilmu jiwa dianggap kurang tepat, karena psikologi memang tidak secara langsung meneliti jiwa, roh atau sukma. ${ }^{5}$

Dalam perkembangan lebih lanjut, terjadi perubahan orientasi dan objek kajian dari psikologi. Psikologi lebih menekankan kajiannya pada sisisisi manusia yang bisa diamati, seperti tingkah laku dan sikapnya. Hal ini terjadi karena mengingat bahwa jiwa -yang menjadi objek kajian pada awal pertumbuhan psikologi- bersifat abstrak, sementara objek kajian ilmu harus dapat diobservasi secara indrawi. Berkaitan dengan ini, Secara rinci Bruno mengemukakan pengertian Psikologi dalam tiga bagian yang saling berhubungan. Pertama Psikologi adalah studi mengenai ruh. Kedua Psikologi adalah ilmu pengetahuan mengenai kehidupan mental, dan, ketiga Psikologi adalah ilmu pengetahuan mengenai tingkah laku organisme. Dengan demikian pengertian psikologi telah mengalami perkembangan dan mengalami pergesaran objek kajian, sehingga mencakup pada objek yang abstrak (ruh dan mental) serta objek yang bersifat konkrit yaitu tingkah laku yang dianggap sebagai manifestasi dari kondisi jiwa dan mental.

Pengertian Psikologi di atas sesuai dengan realita yang terjadi selama ini, yakni bahwa para psikolog pada umumnya menekankan penyelidikan terhadap perilaku manusia yang bersifat jasmaniah yaitu pada ranah psikomotor dan yang bersifat rohaniah yakni ranah kognitif dan afektif. Tingkah laku psikomotor bersifat terbuka, seperti berbicara, duduk, berjalan, mebaca dan sebagainya. Sedangkan tingkah laku kognitif dan

5 Ahmadi Anas dan Mohammad Jauhar, Dasar-Dasar Psikolinguistik (Jakarta: Prestasi Pustakaraya, 2015), h. 33. 
Hasan Hasan: Psikolinguistik: Urgensi dan Manfaatnya Pada Program Studi Pendidikan Bahasa Arab

afektif bersifat tertutup, seperti berpikir, berkeyakinan, dan berperasaan. Psikologi sangat berkaitan erat dengan kehidupan manusia dalam segala kegiatannya yang sangat luas. Dari beberapa pengertian di atas dapat disimpulkan bahwa Psikologi ialah ilmu pengetahuan yang mengkaji tentang prilaku manusia baik yang tampak (bersifat jasmaniah) maupun yang tidak tampak (rohaniah).

Adapun mengenai definisi dari Linguistik, banyak para ahli yang berusaha memberikan rumusan, diantaranya Andre Martinet mengemukakan bahwa linguistik adalah telaah ilmiah mengenai bahasa manusia. Abdul Chaer juga memberikan pengertian yang simpel dengan mengartikan Linguistik sebagai ilmu bahasa atau ilmu yang mengambil bahasa sebagai objek kajiannya .

Sehubungan dengan Psikolinguistik, yang merupakan studi antardisipliner antara psikologi dan linguistik, banyak sekali definisidefinisi yang telah diberikan oleh para ahli. Untuk lebih jelasnya, berikut ini dikemukakan beberapa definisi Psikolinguistik.

Secara lebih rinci Chaer berpendapat bahwa psikolinguistik mencoba menerangkan hakikat struktur bahasa, dan bagaimana struktur itu diperoleh, digunakan pada waktu bertutur, dan pada waktu memahami kalimat-kalimat dalam pertuturan itu.

Samsunuwiyati Marat menyebutkan bahwa Level membagi Psikolinguistik ke dalam tiga bidang utama, yaitu:

a. Psikolinguistik umum yaitu suatu studi mengenai bagaimana pengamatan atau persepsi orang dewasa tentang bahasa dan bagaimana ia memproduksi bahasa.

b. Psikolinguistik Perkembangan yaitu suatu psikologi mengenai perolehan bahasa pada anak-anak dan orang dewasa, baik perolehan bahasa pertama (bahasa ibu) maupun bahasa kedua.

c. Psikolinguistik Terapan adalah aplikasi dari teori-teori psikolinguistik dalam kehiupan sehari-hari pada orang dewasa ataupun pada anakanak. ${ }^{6}$

Ada pendapat yang menarik yaitu membuat kesimpulan yang membuat perbedaan antara psikolinguistik dan psikologi bahasa. Psikolinguistik adalah cabang dari linguistik sedangkan psikologi bahasa

6 Samsunuwiyati Mar'at, Psikolingusitik Suatu Pengantar, keempat (Bandung: Refika Aditama, 2015), h. 1-2. 
Hasan Hasan: Psikolinguistik: Urgensi dan Manfaatnya Pada Program Studi Pendidikan Bahasa Arab

adalah cabang dari psikologi. Psikolinguistik menekankan kajiannya pada hubungan antara tingkah linguistik dan proses psikoligis yang menandai tingkah laku tersebut. Seseorang menggunakan istilah linguistik dalam kaitannya dengan teori dan proses psikoogis seperti kaidah kebahasaan yang berkaitan dengan memori, persepsi, atensi dan pembelajaran. Sementara ahli psikologi bahasa menekankan aspek psikologis dalam penggunaan bahasa seperti bagaimana memori mempengaruhi produksi ujaran dan pemahaman.

Psikologi bahasa berkaitan dengan psikolinguistik dalam hal kajiannya. Tiga komponen utama psikologi bahasa komprehensif, produksi dan pemerolehan bahasa. Sementara itu, psikolinguistik berkenaan dengan proses mental dalam aspek perencanaan, produksi, persepsi, dan pemahaman terhadap tuturan atau ujaran.

Psikolinguistik adalah bagian dari linguistik interdisipliner, merupakan perpaduan antara psikologi dan linguistik yang mengkaji hubungan minda manusia dan bahasa. ${ }^{7}$

Psikolinguistik menyatukan perangkat teoritis hingga empiris baik psikologi maupun linguistik untuk mengkaji proses-proses mental yang mendasari pemerolehan serta penggunaan bahasa.

Psikolinguistik merupakan ilmu interdisipliner dengan tujuan untuk membuat teori yang koheren tentang cara bagaimana suatu bahasa diproduksi dan dipahami. Jadi dapat diambil kesimpulan bahwa yang dinamakan Psikolinguistik adalah terkait erat dengan dengan proses berbahasa. Psikolinguistik dalam pengertian ini juga bertujuan untuk menjelaskan bagaimana pembicara mengatur komunikasi dengan pendengar dan bagaimana komunikasi pembaca dan penulis. Psikolinguistik menghubungkan wilyah-wilayah yang terkait dengan teori linguistik dan di wilayah-wilayah di luar linguistik demi membantu komunikan memhami serta memproduksi gagasan mereka. Fokusnya adalah bagaimana bahasa digunakan secara aktual.

Berdasarkan beberapa pengertian di atas maka dapat ditarik kesimpulan bahwa Psikolinguistik adalah ilmu yang membahas tentang seluk beluk bahasa, hubungan antara bahasa dan otak serta proses pemerolehan bahasa dan struktur kaedah bahasa tersebut.

7 Tadkiroatun Musfiroh, Psikolinguistik Edukasional Psikolinguistik Untuk Pendidikan Bahasa, Kedua (Yogyakarta: Tiara Wacana Yogya, 2017), h. 1. 
Hasan Hasan: Psikolinguistik: Urgensi dan Manfaatnya Pada Program Studi Pendidikan Bahasa Arab

Gagasan pemunculan psikolinguistik sebenarnya sudah ada sejak tahun 1952, yaitu sejak Social Science Research Council di Amerika Serikat ketika tiga orang linguis dan tiga orang psikolog berkumpul untuk mengadakan konferensi interdisipliner. Namun secara formal istilah Psikolinguistik digunakan sejak tahun 1954 dalam buku Charles E. Osgood dan Thomas A. Sebeok yang berjudul Psycholinguistics : A Survey of Theory and Research Problems. Sejak itu istilah tersebut sering digunakan. ${ }^{8}$ Pada awalnya disiplin ilmu ini dikenal sebagai linguistik psycology dan ada juga yang menyebutnya sebagai psycology of language. Kemudian dengan adanya penelitian yang lebih sistematis dan terarah maka lahirlah satu disiplin ilmu yang kemudian dipatenkan dengan sebutan Psikolinguistik. Walaupun disebutkan di atas kemunculan pertama istilah psikolinguistik sudah ada sejak tahun 1952 dan mayoritas pada tahun itulah munculnya ilmu baru yaitu yang dinamakan psikolingusitik. Meskipun sebenarnya psikolinguistik telah dipelajari dan didiskusikan terutama di Jerman sejak abad ke 19 hanya saja menggunakan dengan istilah yang lain. Hal tersebut dapat dibuktikan dengan adanya bangunan Laboratorium Psikologi di Leipzig, Jerman yang dibangun oleh Wundt yang dikenal dengan Bapak Psikologi Eksprimen. Di samping itu juga Wundt juga yang telah memeperkenalkan apa yang pada waktu itu disebut dengan Psikologi Bahasa (Psychologie Der Spracher) yang materinya tidak jauh berebda dengan materi yang dibicarakan di psikolinguistik. ${ }^{9}$ 2. Ruang Lingkup Psikolinguistik

Sebagai disiplin ilmu baru yang berdiri sendiri, Psikolinguistik memiliki scope kajian atau ruang lingkup pembahasannya. Berkaitan dengan hal ini Yudibrata,dkk. menyatakan bahwa Psikolinguistik meliputi pemerolehan atau akuaisisi bahasa, hubungan bahasa dengan otak, pengaruh pemerolehan bahasa dan penguasaan bahasa terhadap kecerdasan cara berpikir, hubungan encoding (proses mengkode) dengan decoding (penafsiran/pemaknaan kode), hubungan antara pengetahuan bahasa dengan pemakaian bahasa dan perubahan bahasa). Sejalan dengan pendapat di atas, Field juga menjelaskan bahwa ruang lingkup Psikolinguistik sebagai berikut: language processing, language storage and access, comprehension theory, language and the brain, and frst language acquisiton '(pemrosesan bahasa, penyimpanan dan pemasukan bahasa,

\footnotetext{
${ }^{8}$ Abdul Chaer, Psikolinguistik Kajian Teoritik (Jakarta: Rineka Cipta, 2015), h. 11.

${ }^{9}$ Mar'at, Psikolingusitik Suatu Pengantar, h. 6.
} 
Hasan Hasan: Psikolinguistik: Urgensi dan Manfaatnya Pada Program Studi Pendidikan Bahasa Arab

teori pemahaman bahasa, bahasa dan otak, dan pemerolehan bahasa pertama).

Sedangkan mengenai pokok bahasan dari Psikolinguistik, Chaer mengemukakan bahwa bahasan psikolinguistik mencakup antara lain:

a. Apakah hakikat bahasa, komponen-komponen bahasa dan sesuatu yang harus dimiliki seseorang agar mampu berbahasa?

b. Bagaimana bahasa itu lahir?

c. Bagaimana bahasa pertama diperoleh ?

d. Bagaimana proses penyusunan kalimat?

e. Bagaimana bahasa itu tumbuh dan mati ?

f. Bagaimana hubungan bahasa dengan pemikiran?

g. Mengapa seseorang mengalami gangguan berbicara dan bagaimana cara menyembuhkannya?

h. Bagaimana cara memperoleh hasil yang baik dalam pembelajaran bahasa?

Dengan melihat pokok bahasan Psikolinguistik di atas, serta kaitannya dengan konteks pembelajaran bahasa, khususnya bahasa Arab, maka dalam tulisan ini penulis akan berusaha menganalisa dan mengkaji secara intens tentang urgensi dan manfaat psikolinguistik dalam pembelajaran bahasa Arab yang ada di prodi PBA.

3. Pembelajaran Bahasa Arab

Menurut Syaiful Bahri Djamarah dan Aswan Zain pembelajaran mengacu kepada pengertian suatu aktifitas (proses) belajar mengajar yang sistematis dan terdiri dari banyak komponen. Masing-masing komponen tersebut tidak bersifat parsial (terpisah) atau berjalan sendiri-sendiri, tetapi harus berjalan secara teratur, saling tergantung, komplementer dan berkesinambungan.

Belajar dan mengajar merupakan dua konsep yang tidak dapat terpisahkan. Belajar merujuk pada apa yang harus dilakukan oleh seseorang sebagai subyek yang menerima pelajaran dan yang belajar (peserta didik), sedangkan mengajar merujuk pada apa yang harus dilakukan oleh guru (pengajar). Sedangkan pembelajaran bahasa Arab berarti proses belajar mengajar melalui transfer ilmu pengetahuan dengan materi ajar berupa bahasa Arab.

Dalam konteks pembelajaran bahasa, dikenal dua tipe pembelajaran bahasa, yaitu naturalistik dan formal. Tipe pembelajaran bahasa naturalistik bersifat alamiah, tanpa guru dan bahkan tanpa kesengajaan dan 
Hasan Hasan: Psikolinguistik: Urgensi dan Manfaatnya Pada Program Studi Pendidikan Bahasa Arab

pembelajaran berlangsung di dalam lingkungan masyarakat. Sedangkan pada tipe formal pembelajaran berlangsung di kelas, dengan adanya guru, materi, alat-alat bantu dan komponen-komponen pembelajaran yang sudah dipersiapkan. Selayaknya, pembelajaran bahasa Arab secara formal akan lebih efektif dan hasil yang diperoleh akan jauh lebih baik dari pada tipe naturalistik. Karena pembelajaran formal dilakukan secara terencana dan sistematis. Namun, kenyataan yang sering terjadi, termasuk yang banyak ditemui di Indonesia, hasil pembelajaran bahasa Arab secara formal kurang menggembirakan. Untuk itu, dipandang sangat perlu untuk melakukan kajian dan analisa guna mengidentifikasi faktor-faktor penghambat keberhasilan dalam belajar bahasa tersebut dan dilakukan perbaikanperbaikan yang semestinya.

Dalam pembelajaran harus adanya penentuan tujuan. Apa saja yang diharapkan kepada anak didik ketika mereka telah melalui proses pembelajaran. Atau dalam kata lain dalam pembelajaran bahasa Arab perlu adanya penentuan kurikulum.

Kurikulum secara etimologi kumpulan rencana pembelajaran yang akan dilaksanakan untuk merealisasikan tujuan pembelajaran. Sedangkan Rusydy Tu'aimah menafsirkan kurikulum dalam konteks pembelajaran bahasa Arab sebagai sistem yang dirancang sedemikian rupa yang bertujuan membekali pelajar bahasa Arab dengan pengalaman belajar, baik kognitif (al ma'rify), afektif (al wijdany), maupun psikomotorik (al nafs al haraky), agar mereka mampu berkomunikasi dengan bahasa Arab. ${ }^{10}$ Menukil dari Tyler, Rusydy Tu'aimah memaparkan empat unsur-unsur kurikulum yang harus diperhatikan oleh pengajar, yaitu:

1. Tujuan Pembelajaran (al ahdaf)

Sebelum pengajar memulai pembelajaran dia sudah mempunyai tujuan yang ingin dicapai. Tujuan inilah yang nantinya fokus pengajar kepada anak didiknya ketika dalam pembelajaran. Tujuan pembelajaran juga mempengaruhi kepada penggunaan sebuah metode dalam mencapai tujuan pembelajaran. Sebagai contoh Jika suatu lembaga pendidikan mengajarkan bahasa Arab bertujuan memberi kemampuan murid-muridnya untuk berbicara dengan menggunakan bahasa Arab maka materi hanya terfokus kepada keterampilan berbicara dengan memakai metode langsung bukannya menggunakan metode membaca (thariqah al qiraah)

${ }^{10}$ Al Marja' Fi Ta'limil Lughoh Al Arabiyah Li al naatiqiin Bi Lughotin Ukhro, 1 (Mekkah: Jami'ah Umm al-Qura, t.t.), h. 125. 
Hasan Hasan: Psikolinguistik: Urgensi dan Manfaatnya Pada Program Studi Pendidikan Bahasa Arab

Rusdy Tu'aimah menetapkan beberapa tujuan pembelajaran bahasa Arab untuk non-Arab sebagai berikut: ${ }^{11}$

a. Pelajar mampu berkomunikasi dengan bahasa Arab hampir atau seperti pemilik bahasa Arab (nathiq bi al 'arabiyyah)

b. Meningkatkan kompetensi bahasa pelajar yaitu: keterampilan mendengar (maharat al istima), berbicara (maharat al kalam), membaca (maharat al qiraah), menulis (maharat al kitabah).

c. Pelajar mengetahui karakteristik bahasa Arab dari aspek fonologi, leksikologi, dan struktur kalimat.

d. Pelajar mengetahui budaya Arab, karakteristik, dan lingkungan orang Arab.

Dalam hal penentuan tujuan di Prodi PBA STIQ Amuntai sudah ditentukan yaitu memberikan kemampuan kepada mahasiswa didik untuk membaca teks bahasa Arab baik itu buku-buku yang konvensional maupun yang modern. Dan hal tersebut juga sesuai dengan hasil keputusan rapat pimpinan dengan dosen-dosen prodi PBA STIQ Amuntai pada tahun 2015. Penentuan buku/kitab pegangan dosen dan mahasiswa pun sudah ditentukan oleh pimpinan kampus.

2. Materi Pembelajaran (al muhtawa)

Materi pembelajaran adalah sekumpulan pengalaman pembelajaran, pengetahuan, dan keterampilan yang ingin disampaikan kepada pelajar agar mereka menguasainya. Materi pembelajaran tidak berjalan maksimal tanpa penggunaan media yang tepat sehingga tercipta sinergi yang baik antara keduanya. Fakta yang ada media pembelajaran bahasa Arab masih tertinggal dengan media pembelajaran bahasa Inggris. ${ }^{12}$ Beberapa pakar memberikan kriteria atau aspek yang layak dipertimbangkan dalam pemilihan materi pembelajaran bahasa Arab, sebagai berikut:

\section{Validitas (al shidq)}

Materi pembelajaran bahasa Arab harus relevan dengan realita kehidupan pelajar, di samping itu ia juga memenuhi standar akademis. Maksud relevan disini adalah materi yang disampaikan itu terjadi di kehidupan sehari-hari dan dialami anak didik.

11 Rusdy Tu'aimah, Ta'lim Al Arabiyah Li Ghoiri Al Natiq Biha: Manaahijuhu Wa Asalibuhu, t.t., h. 49.

${ }^{12}$ Hasan Hasan, "Optimalisasi Media Dua Dimensi Tanpa Proyeksi Dalam Meningkatkan Pemerolehan Bahasa Arab Siswa," Jurnal Al Maqayis 3, no. 1 (2015): h. 2. 
Hasan Hasan: Psikolinguistik: Urgensi dan Manfaatnya Pada Program Studi Pendidikan Bahasa Arab

\section{Signifikansi (al ahammiyah)}

Materi dianggap penting jika mempunyai urgensi dalam kehidupan pelajar, seperti pengetahunan, nilai-nilai dalam masyarakat, keterampilanketerampilan yang mempunyai relevansi dan urgensi dalam menjadikan mereka orang yang bermanfaat bagi agama dan bangsa.

\section{Kecenderungan Pelajar (al muyul wa al ihtimamat)}

Pemilihan materi pembelajaran sesuai dengan kecendurungan pelajar, misalnya pengajar dapat memilih beberapa tema pembelajaran bahasa Arab yang sesuai dengan hobi pelajar dengan memperhatikan tujuan pembelajaran.

\section{Learned Ability (Qabiliyah li al ta'lim)}

Materi pembelajaran disesuaikan dengan tingkat kemampuan, umur pelajar, dan juga memperhatikan perbedaan antara individu, dengan memperhatikan prinsip-prinsip pembelajaran secara bertahap

\section{Universalitas ('alamiyah)}

Materi pembelajaran dikatakan baik, jika ia mencakup aspek universalitas bagi pelajar sehingga bisa digunakan di mana saja dan tidak terbatas pada daerah atau budaya tertentu. Dalam artian semua orang bisa menggunakan tanpa adanya batasan dalam penggunaannya.

\section{Metode Pembelajaran (thariqah)}

Metode pembelajaran adalah sekumpulan teknik yang digunakan untuk mengarahkan kegiatan pembelajaran ke arah tujuan pembelajaran yang telah ditetapkan sebelumnya. ${ }^{13}$

Metode pembelajaran bahasa sangat beraneka ragam, sehingga seorang guru harus jeli dalam memilih metode yang akan dipakai dalam pembelajaran. Yang harus dicatat, bahwa tidak ada metode yang paling benar dan cocok untuk digunakan di segala kondisi, pelajar atau masyarakat.

Metode pembelajaran bahasa Arab secara garis besar, dapat dibedakan menjadi dua macam: ${ }^{14}$ pertama, metode pembelajaran bahasa Arab yang terfokus pada "Bahasa sebagai budaya ilmu", sehingga belajar bahasa Arab berarti belajar secara mendalam tentang seluk-beluk ilmu bahasa Arab, baik aspek gramatika/sintaksis (qawa'id al-nahwi), morfem/morfologi (qawa'id al-sharf), ataupun sastra (adab). Kedua, metode pembelajaran

${ }^{13}$ Mahmud Kamil Naqoh, Thoroiq tadris al lughoh al Arabiyah li ghoiri natiqiin bihaa, (Kairo: Munaddzomah Islamiyah Li Tarbiyah Wa Al Ulum, 2003), h. 69.

${ }^{14}$ Diklat Profesi Guru, LPTK Fakultas Tarbiyah IAIN Sunan Ampel, 28 juni 2010 
Hasan Hasan: Psikolinguistik: Urgensi dan Manfaatnya Pada Program Studi Pendidikan Bahasa Arab

bahasa Arab modern yang berorientasi pada tujuan bahasa sebagai alat. Artinya, bahasa Arab dipandang sebagai alat komunikasi dalam kehidupan modern, sehingga tujuan pembelajaran adalah kemampuan menggunakan bahasa aktif maupun pasif.

Diantara metode pembelajaran bahasa yang terkenal adalah:

\section{Metode qowaid dan terjamah (thariqah al qawaid wa al tarjamah)}

Metode yang sering dikenal dengan metode tradisional ini berasumsi pembelajaran bahasa hakikatnya adalah belajar tata bahasa. ${ }^{16}$ Pembelajaran bahasa menurut metode ini adalah memberikan kemampuan kepada pelajar untuk membaca naskah teks Arab dan juga memiliki nilai disiplin intelektual kepada pelajar. Metode ini juga dikenal dengan metode klasikal atau juga tradisional. ${ }^{15}$

\section{Metode langsung (thariqah al mubasyirah)}

Metode ini lahir sebagai bentuk protes terhadap metode qowaid dan terjamah, lahir pada pertengahan abad ke 19 oleh F. Gouin (1980-1992). Pembelajaran dengan metode ini bertujuan untuk memberikan kompetensi berbicara kepada pelajar. Oleh karena itu, pembelajaran dilakukan dengan menggunakan bahasa Arab, hal ini didasarkan kepada proses pemerolehan anak terhadap bahasa pertama. ${ }^{16}$

\section{Metode silent way (thariqah al shamitah)}

Metode yang digagas oleh C. Gatteno (1972). Gatteno sendiri dikenal ahli pengajaran bahasa yang menerapkan prinsip-prinsip kognitivisme dan ilmu filsafat dalam pengajarannya. ${ }^{17}$ Ia mempunyai persamaan ide dengan teori kognitivisme Noam Chomsky, yang meyakini bahwa pelajar telah dibekali kemampuan bahasa bawaan. Sehingga pembelajaran sangat bergantung kepada diri pelajar, tugas guru sebagai fasilitator, mengoreksi, mengarahkan dan memberi rangsangan agar mereka mampu mengeluarkan kemampuan mereka tersebut. Pelajar menerima rangsangan tersebut yang kemudian diolah dalam diri mereka untuk dijadikan bagian dari diri mereka. Praktek metode silent way adalah guru seminimal mungkin memberikan contoh. Sebaliknya, ia harus memberikan porsi pembelajaran sebanyak-banyak kepada pelajar.

\footnotetext{
${ }^{15}$ Fachrurrozi dan Mahyudin, Pembelajaran Bahasa Asing, h. 39.

${ }^{16}$ Abdul Majid 'Azali, Ta'Allum Al Lughot Al Khayyah Wa Taklimuha: Baina Nadhariyyah Wa Tadbiq, (Kairo: Maktabah Lubnan), h. 42.

${ }^{17}$ Fachrurrozi dan Mahyudin, Pembelajaran Bahasa Asing, h. 109.
} 
Hasan Hasan: Psikolinguistik: Urgensi dan Manfaatnya Pada Program Studi Pendidikan Bahasa Arab

4. Evaluasi Pembelajaran (al taqwim)

Dari pemaparan di atas, dapat disimpulkan bahwa hubungan antara empat unsur kurikulum dalam proses pembelajaran adalah hubungan timbal balik. Tujuan pembelajaran ditentukan sebelum suatu program pembelajaran dilaksanakan, yang kemudian menjadi penentu dalam pemilihan metode maupun materi pembelajaran. Sedangkan evaluasi tidak kalah penting. Unsur ini merupakan muhasabah bagi pelaksanaan program pembelajaran baik ketika masih berlangsung atau setelah pelakasanaan pembelajaran.

\section{Psikolinguistik dalam mengatasi kesulitan Belajar Bahasa Arab}

Dalam beberapa kasus, sering ditemui beberapa contoh kesalahan yang sering terjadi pada pelajar bahasa Arab yang non Arab ketika mereka mulai berbicara dan berbahasa Arab. Kesalahan-kesalahan ini dilatarbelakangi oleh beberapa faktor, baik faktor internal anak didik, seperti motivasi, waswas dan sebagainya, baik faktor dari luar anak didik, seperti guru, lingkungan, dan bahkan bahasa itu sendiri.

Adapun kesalahan-kesalahan yang dilakukan oleh pelajar bahasa Arab, dapat dilatarbelakangi oleh beberapa faktor, baik intrinsik maupun ekstrinsik, diantaranya adalah :

a. Kesalahan dalam pemilihan strategi pembelajaran, yaitu hanya memfokuskan pada penghafalan kosa kata dan kaidah bahasa tanpa memperdulikan terhadap fungsi dan penggunaan kata baik dalam lisan maupun tulisan. Hal ini dapat mengakibatkan pada :

1) Anak didik sukar melafalkan dan membedakan suara huruf-huruf yang berdekatan, seperti $\tau$ dan $\rightarrow, \oplus$ dan $b$.

2) Cenderung melakukan generalisasi dalam kaedah bahasa, seperti menjamak kan semua kata dengan bentuk jamak qiyasi (muzdakkar salaim atau muannats salim), contoh رَجلون menjadi رَجل seharusnya رجال

b. Intervensi bahasa, yaitu pengaruh dari bahasa pertama terhadap bahasa kedua (Arab), baik pada aspek suara, intonasi, gaya bahasa dan susunan kalimat.

c. Penguasaan kosa kata aktif dalam bahasa Arab yang sangat terbatas, sehingga sering mengakibatkan pencampuradukkan dan penggunaan beberapa kata atau istilah dari bahasa pertama ketika menggunakan bahasa Arab, sebagai bahasa kedua. Di samping itu, terkadang penyebab kesalahan yang dilakukan oleh pembicara di antaranya disebabkan 
Hasan Hasan: Psikolinguistik: Urgensi dan Manfaatnya Pada Program Studi Pendidikan Bahasa Arab

kesaratan beban mental pada anak didik yaitu perasaan waswas, takut salah, ragu-ragu dan sebagainya ketika berbicara hanya memfokuskan kepada kaidah nahwu sehingga memunculkan perasaan takut salah (hal ini dalam kemampuan kalam sangat dihindari), atau karena penutur kurang menguasai materi, terpengaruh oleh perasaan afektif, kesukaran melafal kata-kata, dan kurang menguasai topik pembicaraan. Dari penyebab kesalahan-kesalahan tadi, dapat diklasifikasikan berdasarkan ranah Psikologi. Penyebab kesalahan berupa intervensi bahasa dan perasaan waswas berkaitan dengan ranah afektif. Penyebab kesalahan berupa kurang menguasai kosa kata aktif, materi atau topik berkaitan dengan ranah kognitif, dan penyebab kesalahan berupa kesalahan pemilihan strategi pembelajaran, kesukaran melafalkan kata dan generalisasi kaedah bahasa berkaitan dengan ranah psikomotor. Contoh-contoh kesalahan dan penyebab kesalahan yang telah dijelaskan tadi menunjukkan bahwa peran psikolinguistik dalam pembelajaran bahasa Arab sangat penting. Peranan Psikolinguistik itu nampak diantaranya saat dilakukan upaya untuk mengidentifikasi faktor-faktor kegagalan dan kesalahan anak didik dalam belajar bahasa Arab serta dapat juga digunakan sebagai alat untuk memecahkan maslah-masalah dan persoalan (problem solving) yang timbul pada konteks pembelajaran bahasa Arab.

Dengan demikian, jelaslah bahwa betapa penting peranan Psikolinguistik dalam pembelajaran bahasa Arab. Guru merupakan subjek dalam proses belajar mengajar, (sebagai fasilitator, informer, maupun sebagai pembimbing) menjadikan anak didik tuntas ber-bahasa. Karena amat pentingnya psikolinguistik dalam pembelajaran bahasa lebih khusus bahasa Arab, tidaklah berlebihan dalam menyebutkan pentingnya mata kuliah psikolinguistik untuk diajarkan pada prodi PBA. Diharapkan mahasiswa setelah lulus dalam mata kuliah ini akan mandiri dalam menentukan solusi dalam pembelajaran bahasa Arab nantinya.

Keberhasilan dalam belajar bahasa Arab banyak dipengaruhi oleh beberapa faktor. Secara garis besar faktor-faktor itu dapat dikelompokkan menjadi dua kelompok besar, yaitu internal atau faktor dari dalam anak didik (masuk dalam wilayah psikolinguistik) dan faktor eksternal atau faktor dari luar diri anak didik, seperti faktor lingkungan keluarga, masyarakat dan sekolah, faktor kebahasaan, kebudayaan, sosial dan etnis. Anak didik yang sehari-hari berada di lingkungan yang menggunakan 
Hasan Hasan: Psikolinguistik: Urgensi dan Manfaatnya Pada Program Studi Pendidikan Bahasa Arab

bahasa Arab, tentu akan lebih berhasil dari pada anak didik lain yang sehariharinya tidak berbahasa Arab.

Untuk mencapai tujuan pengajaran bahasa Arab, harus dikaitkan dengan status bahasa itu sendiri. Dengan mengetahui status, jumlah penutur dan bahasa yang dikuasai anak didik, pengembang kurikulum, dapat membuat persiapan dengan baik. Di Indonesia ada tiga macam bahasa, yaitu bahasa Indonesia, bahasa daerah dan bahasa asing. Bahasa Indonesia adalah bahasa nasional dan bahasa resmi negara. Bahasa daerah yaitu bahasa ibu atau bahasa yang sering digunakan sehari-hari oleh anak didik ketika berinteraksi dengan masyarakat setempat. Sedangkan bahasa asing adalah bahasa yang berasal dari negara lain, digunakan dalam interaksi atau kegiatan ilmiah. Bahasa Arab termasuk dalam kategori bahasa asing ini.

Dengan memahami status bahasa, peran bahasa di tengah penuturnya dan tujuan yang diinginkan oleh para anak didik, maka perencanaan dan pengembangan kurikulum, pengajar bahasa, program pengajaran formal, buku teks dan seleksi anak didik dapat dipersiapkan secara matang guna mencapai tujuan akhir yang diharapkan. Masalah Psikolinguistik ini, tidak sulit jika masih dalam satu rumpun. Bila kedua bahasa tersebut berbeda rumpun masalahnya akan sangat sulit, karena kedua bahasa itu memiliki struktur fonetis, morfologis dan sintaksis yang berbeda.

Dalam bidang fonologi, masyarakat Indonesia multikultural, memiliki beraneka dialek yang berbeda pola fonologis, intonasi dan nada bacaannya dengan bahasa Arab. Sehingga dalam menyalin dari bahasa Indonesia ke bahasa Arab, sebagian besar anak didik menggunakan pola yang terdapat dalam pola bahasa Indonesia. Seperti suara huruf د (zdal) disamakan dengan "d", ع ( 'ain) disamakan dengan "a", ش (syin (disamakan dengan "s", dan sebagainya. Kesalahan pola fonetik semacam ini dapat berpengaruh pada kesalahan anak didik dalalm melafalkan bahasa, bahkan terkadang dapat menyebabkan perubahan makna leksikan dan pengaburan arti.

Untuk mengatasi berbagai kesulitan seperti pada paparan di atas, dapat diambil beberapa langkah atau pola penyelesaian dalam rangka memperoleh hasil pembelajaran bahasa Arab yang lebih baik. Pola-pola tersebut di antaranya: 
Hasan Hasan: Psikolinguistik: Urgensi dan Manfaatnya Pada Program Studi Pendidikan Bahasa Arab

a. Analisis kontrastif, yaitu dengan membandingkan pola yang terdapat dalam bahasa pertama dengan pola yang terdapat dalam bahasa kedua. Pola yang berbeda sering diberi latihan, sedangkan pola yang mirip atau sama cukup diberi latihan sekedar saja. Linguistik kontrastif beranggapan bahwa penguasaan suatu bahasa tidak lain dari pembentukan kebiasaan, maka butuh latihan terus menerus sehingga terbentuk kebiasaan seperti ketika mempelajari bahasa pertama. Analisis kontrastif ini juga memiliki fungsi klarifikatif, komplementer, preventif dan kuratif. ${ }^{18}$

b. Pemilihan Metode Pengajaran yang tepat untuk mengajarkan bahasa Arab, pilihlah metode yang cocok dan tepat dengan materi bahasa. Beberapa metode yang dapat digunakan dalam pengajaran bahasa, seperti metode langsung, alamiah, psikologis, fonetik, membaca, tata bahasa, terjemah, terjemah-tata bahasa, dan sebagainya. Penggunaan sebuah metode dalam pembelajaran haruslah juga melihat dari kondisi psikologis peserta didik. Tidaklah bisa mengambil kesimpulan bahwa satu metode tertentu sebagai metode yang paling baik di antara metodemetode yang ada.

Pemberian motivasi dan dorongan secara kontinu terhadap anak didik, karena dalam pembelajaran bahasa kedua diyakini bahwa orang yang memiliki motivasi dan dorongan yang kuat pada dirinya akan jauh lebih berhasil dibandingkan orang yang kurang memiliki motivasi dan dorongan dalam belajar.

C. Kesimpulan

Pengertian psikolinguistik berdasarkan ruang lingkupnya adalah ilmu yang mempelajari aktivitas berbahasa manusia, baik pemerolehan, pemahaman, dan penggunaan bahasa, psikologi dan linguistik, merupakan disiplin ilmu yang mempelajari dan memfokuskan kajiannya pada bahasa, dengan segala karakteristiknya, yang meliputi perilaku berbahasa, baik yang tampak maupun yang tidak tampak, pemerolehan bahasa, dan pemproduksian bahasa serta proses yang terjadi di dalamnya. Sedangkan pembelajaran bahasa Arab adalah bidang yang membahas teori, metode, teknik untuk memberi kemampuan kompetensi bahasa (mendengar, berbicara, membaca, menulis) bahasa tujuan kepada pelajar. Baik

${ }^{18}$ Moh Ainin, Analisa Bahasa Pembelajar Bahasa Arab Sebagai Bahasa Asing; Kajian analisis Kontrastif, kesilapan, dan Koreksi Kesilapan (Malang: Misykat, 2011), h. 37. 
Hasan Hasan: Psikolinguistik: Urgensi dan Manfaatnya Pada Program Studi Pendidikan Bahasa Arab

psikolinguistik maupun pembelajaran bahasa Arab, keduanya mempunyai bidang kajian yang sama yaitu bahasa.

Sebagai suatu disiplim ilmu yang berdiri sendiri, Psikolinguistik memiliki ruang lingkup kajian yang meliputi hubungan antara bahasa dan otak, hubungan antara bahasa dan perilaku manusia, pemerolehan bahasa, dan pemproduksian bahasa. Sedangkan pokok bahasan dari ilmu ini adalah mengenai hakekat bahasa, komponen bahasa, sejarah bahasa, proses penyusunan kalimat dalam berahasa, serta bagaimana memperoleh hasil yang baik dalam pembelajaran bahasa.

Dalam pembelajaran bahasa Arab sebagai bahasa kedua (second language) Psikolinguistik memiliki peranan dan kontribusi yang cukup besar dan sangat penting. Peranan itu dapat terlihat misalanya dalam menelaah latar belakang permasalahan dari kesalahan-kesalahan dalam berbahasa dan belajar bahasa, serta langkah-langkah dalam menaganinya (problem solving). Dengan memahami psikolinguistik seorang guru juga akan mampu memahami proses yang terjadi dalam diri anak didik sehingga manakala kemampuan dan keterampilan anak didik dalam berbahasa Arab bermasalah, maka guru akan mampu mencarikan soslusinya dan memperbaiki sistem pengajaran atau strategi pembelajarannya, jika masalah itu ditimbulkan oleh kesalahan penggunaan strategi pembelajaran yang ia gunakan.

Di dalam kurikulum pendidikan bahasa pada lembaga pendidikan tenaga kependidikan, mata kuliah psikolinguistik dimasukkan dalam kelompok mata kuliah proses belajar-mengajar, dan bukan pada kelompok mata kuliah linguistik/kebahasaan. Hal ini menandakan besarnya peranan ilmu psikolinguistik dalam pembelajaran bahasa Arab.

Mata kuliah psikolinguistik bagi prodi PBA STIQ Amuntai merupakan mata kuliah yang baru karena baru dimasukkan ke dalam kurikulum prodi pada tahun 2016 dan dipelajari pada semester 4. Walaupun sebenarnya terlambat dalam memasukkan mata kuliah psikolinguistik ini ke dalam kurikulum prodi PBA STIQ Amuntai. Diharapkan ketika lulus mata kuliah ini mahasiswa didik dapat memahami teori-teori tentang psikologi dan lingusitik dan untuk selanjutnya digunakan dalam memahami teori tentang pembelajaran bahasa sekaligus dipraktikkan ketika sudah mengajar nantinya. 
Hasan Hasan: Psikolinguistik: Urgensi dan Manfaatnya Pada Program Studi Pendidikan Bahasa Arab

\section{DAFTAR PUSTAKA}

Ahmadi Anas, dan Mohammad Jauhar. Dasar-Dasar Psikolinguistik. Jakarta: Prestasi Pustakaraya, 2015.

Ainin, Moh. Analisa Bahasa Pembelajar Bahasa Arab Sebagai Bahasa Asing;

Kajian analisis Kontrastif, kesilapan, dan Koreksi Kesilapan. Malang: Misykat, 2011.

Al Marja' Fi Ta'limil Lughoh Al Arabiyah Li al naatiqiin Bi Lughotin Ukhro. 1. Mekkah: Jami'ah Umm al-Qura, t.t.

Chaer, Abdul. Psikolinguistik Kajian Teoritik. Jakarta: Rineka Cipta, 2015.

Fachrurrozi, Aziz, dan Erta Mahyudin. Pembelajaran Bahasa Asing. Jakarta: Bania Publishing, 2010.

Hasan, Hasan. "Keterampilan Mengajar Bahasa Arab Materi istima Menggunakan Media Lagu." Al Qalam: Jurnal Ilmiah Keagamaan dan Kemasyarakatan 10, no. 19 (2017): 21.

-_- "Optimalisasi Media Dua Dimensi Tanpa Proyeksi Dalam Meningkatkan Pemerolehan Bahasa Arab Siswa." Jurnal Al Maqayis 3, no. 1 (2015).

- - - Penerjemahan Arab-Indonesia (Antara Bahasa dan Budaya). Banjarbaru: Atap Buku, 2017.

Mar'at, Samsunuwiyati. Psikolingusitik Suatu Pengantar. Keempat. Bandung: Refika Aditama, 2015.

Musfiroh, Tadkiroatun. Psikolinguistik Edukasional Psikolinguistik Untuk Pendidikan Bahasa. Kedua. Yogyakarta: Tiara Wacana Yogya, 2017.

Tu'aimah, Rusdy. Ta'lim Al Arabiyah Li Ghoiri Al Natiq Biha: Manaahijuhu Wa Asalibuhu, t.t.

Wahab, Muhbib Abdul. Pemikiran Linguistik Tammam Hassan Dalam Pembelajaran Bahasa Arab. Jakarta: UIN Syarif Hidayatullah Jakarta, 2009. 